\title{
THE ESSENCE OF TRANSPARENCY PRINCIPLE IN THE PROCUREMENT OF GOODS AND GOVERNMENT SERVICES THROUGH THE EXCHANGE (RUILSLAG): TOWARDS GOOD GOVERNANCE IN PUBLIC SERVICES
}

\begin{abstract}
Ainuddin ${ }^{*}$ Idrus Abdullah ${ }^{* *}$, Djumardin $^{* * *}$ \& I Nyoman Nurjaya ${ }^{* * * *}$
The paper concerns to an urgent principle that should be accommodated within democratic nature namely principles of transparency particularly in the procurement of goods and Government services as stipulated in the Law No. 1 Year 2004 on State Treasury in relation to Presidential Decree No. 4 Year 2015 regarding Procurement of Goods and Government Services and Government Regulation No. 27 Year 2014 on the Management of Goods belonging to Central and Regional Government and Miniter Regulation No. 17 Year 2007 concerning Technical Guidelines for the Regional Government Goods Exchange. The paper based on the outcomes of the research namely normative legal research that examine and analyse the principles of transparency in the procurement of goods and services of the Government through the method and mechanism of the Exchange (ruilslag). The research findings indicated that the principle of transparency in procurement of goods and Government services through ruilslag is important to be accomodated and regulated for the purpose of pursuing public services of the Government in order to realising prosperity of the people of Indonesia in order to pursuing general good governance principle as mandated by the 1945 Constitution.
\end{abstract}

INTRODUCTION

I. CONSTitutional AND LEGAL FRAMEWORK OF THE PROCUREMENT GOODS AND GOVERNMENT SERVICES ..............................................................602 II. TRANSPARANCY PRINCIPLE IN THE PROCUREMENT GOODS AND GOVERNMENT SERVICES THROUGH THE EXCHANGE (RuISLAG) METHOD AND

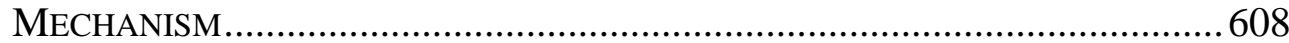

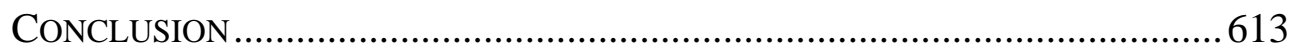

\footnotetext{
* Ainuddin, Student of Doctoral Law Study Program, Postgraduate Program, Mataram University, Indonesia. Research fields: Administrative Law and Agrarian Law.

** Idrus Abdullah, Professor of Law Faculty of Law Mataram University, research fields:

Constitutional Law and Legal Anthropolgy.

*** Djumardin, Doctor of Law Faculty of Law Mataram University, research fields: Economic Law and Administrative Law.

**** I Nyoman Nurjaya, Professor of Law Faculty of Law Brawijaya University, research fields: Environemntal Law and Anthropology of Law.
} 


\section{INTRODUCTION}

Indonesia is the rule of law ${ }^{1}$ state and democratic country means putting interests to ensure supremacy of law and to provide prosperity for the people of Indonesia. It is at once mandated by the 1945 Constitution that should be implemented by the Government to manage state's assets and natural resources to realise genuine welfare for the greatest people of Indonesia. $^{2}$ The 1945 Constitution particularly Article 33 Paragraph (3) clearly states that "the Earth and water and natural resources contained therein controlled by the State and should be utilized for the welfare of the whole people of Indonesia”.

The mentioned principle has afterward been elaborated in the time of the enactment Act No. 5 Year 1960 concerning the Basic Agrarian Law (BAL) in order to realise and achieve the main objectives of Article 33 Paragraph (3) the 1945 Constitution. In particular Article 2 Paragraph (1) BAL regulated that the State has not been in acting as the owner of the natural resources of the country but having the State's right to control and is authorized to:

1. Set up and organise allocation, use, supplies and care for the earth, water and air space;

2. Determine and regulate legal relations with the people of the earth, water and air space;

3. Determine and regulate legal relations between the people and the legal acts which the earth, water and space.

Based on the State's rights to control leads the management rights granted to the Government and State's institutions hold authorities to establish policies along with the policies that does not conflict with national interests. In the era of national development the meaning and function of the agrarian resources especially lands in the eyes of the Government is no longer related to the meaning as magical religious wealth as it was believed by the Indonesian people; The lands has covered a very important meaning that the land is not the only important when viewed from the economic aspect, but also includes social and cultural dimension as well as political and legal, and territory security of the country. ${ }^{3}$

Recognizing the importance function and meaning of the lands as mentioned above, it is therefore the Government mandated legal obligation

\footnotetext{
${ }^{1}$ Mukthie Fadjar, Tipe Negara Hukum (Type of The Rule of Law State) 8 (Malang: Bayu Media Publishing, 2004).

${ }^{2}$ Dahlan Thaib, Kedaulatan Negara Hukum dan Konstitusi (The Rule of Law State Sovereignty and Constitution) 21 (Liberty, Yogyakarta, 1999).

${ }^{3}$ A. P. Parlindungan, Komentar Atas Undang-Undang Pokok Agraria (Comments over Basic Agrarian Law) 45 (Bandung: Mandar Maju, 1994).
} 
to improve and set the proper management of lands as natural resource mainly for the welfare and prosperity of the people in accordance to the provisions of the applicable State's legislation. In this sense the BAL mentioned that one of the objectives need to reach is to build foundations that provide legal certainty regarding the rights to lands for all the people of Indonesia. In order to increase the effectiveness of the management of State's land, it is necessary to correct the proper management and in terms of management of assets of the Government include Central and Regional Government in the decentralisation period of time. ${ }^{4}$

In association with the management of goods as assets of the Government has been stipulated in the Government Regulation No. 27 Year 2014 regarding Management of the Government's Assets. In relation to legitimacy of the Central and Regional Government in the procurement of goods for public services has been stipulated within Presidential Decree No. 4 Year 2015 concerning the Procurement of Goods and Government Services. It is clearly defined that one method that can be used by the Government in the procurement of goods and services that is through the Exchange or commonly called the Ruilslag in Dutch. In this respect, Ruilslag means a goods exchange particularly lands or buildings included the exchange of rights to land or the building between the Government and other parties it could be individual or corporation as legal subject with the principle of mutually benefit. ${ }^{5}$

Ruislag has commonly been employed in the case of unavailability of Government's budget for the purpose of procurement office buildings and fasilities for realising public services. In this sense goods mainly lands required as the assets of the Government is allowed by laws and legislation to be exchanged along in accordance with regional development spatial planning as well as for other reasons to improve the effectiveness of Government's public services. It could be a legal way to set the operational expenditure of the Government by way of exchange (ruilslag) due to limitation financial provided by the Government for conducting public services and realising prosperity and welfare for the people of Indonesia as legal obligation mandated by the 1945 Constitution. ${ }^{6}$

\footnotetext{
${ }^{4}$ Koswara, Otonomi Daerah untuk Demokrasi dan Kemandirian Rakyat (Regional Authonomy for the Democracy and Prosperity of the People), 56 (Pariba, Jakarta, 2001).

${ }^{5}$ Muchamad Nurachmad, Buku Pintar Pengadaan Barang dan Jasa Pemerintah (Guidence for the Procurement of Goods and Government's Services), 19 (Visi Media, Jakarta, 2011).

${ }^{6}$ Imam Kuswahyono, Politik Hukum Tukar Menukar Barang Milik Negara/Daerah dalam Konteks Pengelolaan Barang Milik Negara/Daerah yang Berkeadilan (Politic of Law in the Enxchange of Government's Goods in the context of Justice in State's Assets Management ), Disertation Postgraduate Program University of Brawijaya, Malang (2016).
} 
Expenses of national development guided by the State's budget which is rules and procedures of the Central and Regional Government in managing State finances. The budget made by the Government and should be approved by the House of People Representatives (DPR). In this respect expenditures that are considered important and urgent in the national development such like of education and people healthy facilities as well as office building and required for public services should be included in the State's budget. In the case of nothing budget available the Government can employ method of ruilslag in the form of exchange agreement in which parties bound themselves to give each other a reciprocal goods based on understanding that the exchange has been binding upon the achievement of an agreement on goods which become object of the agreement.

In this sense the agreement can also be seen as a legal obligation that provide rights and duties for parties. Each party gets the right to demand handing over property rights on goods which become legal object of the agreement. The act of transfer of the ownership of each item is really legal conduct that so called levering or surrender property rights. The name of purchase agreement within Indonesia private law is commonly about goods with money, but in the exchange (ruilslag) agreement could be a legally transaction concerning goods with goods that owned by parties.

The legal problem in relation to implementing procurement of goods and Goverment's services through the way of ruilslag in the country is that there is not found the exactly formulation for the Government as well as private or corporation as parties especially on how the procurement of goods and services through ruilslag ensures transparency in the form of greater openness of information as to which stipulated in the Act No. 14 Year 2008 on Public Information. In this respect, legal dimension and the existence of underlying ruilslag in which the Government in one side and the party as the legal subject in the exchange agreement need a legal certainty and openness natura as to fullfil transparancy principle in the procurement goods and Government services. ${ }^{7}$

In line with the Government objectives to govern the State with rights and obligations and there are a number of tasks that must be executed by the Government. One of the important tasks of the Government is in building system of management of goods and the accountability of financial expenditure based on the rule of administrative law that governs the State treasury as regulated within the Act No. 1 of 2004 on State Treasury. According to the Act No. 1 Year 2004 the State Property and Assets of the

\footnotetext{
${ }^{7}$ Abu Sopian, Dasar-dasar Pengadaan Barang dan Jasa Pemerintah (Basic Regulation for the Procurement of Goods and Government's Services), 45 (In Media, Palembang, 2014).
} 
Government are managed by the Ministery of Finance. In particular in the provisions of Article 45 Paragraph (1) State Treasury Act of 2004 regulated that the assets of the Government is in principally to implement the tasks of the Central and Regional Government non-transferable. But there is a legal exception according to Paragraph (2) of the said Article namely alienation of the Government's assets and property can be done in a way of sold, exchanged, assigned or included as Government capital after obtaining the approval of the House of People Representative (DPR) or the Regional House of People Representative Regional (DPRD) for the Regional Government.

Furthermore according to the Article 64 Paragraph (1) Government Regulation No. 27 Year 2014 concerning the Central and Regional Government's Assets Management, the exchange (ruilslag) of goods and property of the Government can be conducted by the considerations as follows:

a. To meet the operational needs of the Government;

b. To optimize the property of the Government;

c. There is no money for budgeting revenue and expenditure of the Government.

In the procurement of goods and services required policies and comprehensive information to the public, especially in the procurement of Government's goods and services through the ruilslag. It is needed that the Government should set up a proper policy on how the clear information can be accessed by public and complaint mechanism should be conducted if the information is not up to the public. That is the so called transparancy principle in the procurement through ruilslag as basic legal instrument that guarantee the right to information of the public, supporting by database facility and means of information and communication, as well as dissemination of complaints procedures. Therefore, any law on transparency is a legal product that is guaranteed to set about the right to access and disseminate information to the public. In the era of information, transparency has become an international etiquette that must be regulated to ensure the implementation of accountable and transparent governance system which is one key to good governance in the country. ${ }^{8}$

Transparency principle in Indonesia has not really been into the spirit of paradigm and ethics in governance. In the Act No. 14 of 2008 on Public Information that defines obligation public bodies to release information actively on the regional development plan, including the budget, planning

\footnotetext{
${ }^{8}$ Meuthia Ganie Rahman, Good Governance, Prinsip, Komponen, dan Penerapannya (Good Governance, Principle, Elements, and Its Implementation), 67 (Komnas HAM, Jakarta, 2000).
} 
and the determination of spatial plans, the implementation of development activities, as well as tasks and functions of the public body concerned, the procedure to obtain public information on a public body. Presence of the rules the only form of justification, that the Government seemed to have good faith and transparent. It is the factor which caused the weaknesses in the procurement system of goods and services of the Government that incomprehension or lay on transparancy principle as embodied in the spirit of good governance principle. ${ }^{9}$

In line to the above description the legal problem in regulating the exchange (ruilslag) of goods as assets and property belonging to the Government is that no limits or benchmarks against reason permissibility of legal act in exchanging possessions of the Government as mentioned in Article 46 Paragraph (1) letter b Law No. 1 of 2004 on State Tresury. Although it has been already stipulated in Article 64 Paragraph (1) letter a to $\mathrm{c}$ in the Government Regulation No. 27 of 2014 regarding the Management of State Assets and Property, however, reason the implementation of the exchange need to be clear in the level of the operational of administration for the optimization of State's assets, unavailability of funds in the budget revenue and expenditure of the Government, and therefore giving rise to interpretations that range from administration officials through discretionary policy oriented. ${ }^{10}$

\section{Constitutional and Legal Framework of the Procurement GoOdS AND GOVERNMENT SERVICES}

In relation to the legal issue such assets and property associated with the Act No. 5 of 1960 on Basic Agrarian Law (BAL) particularly Article 2 Paragraph (1) stated that on the basis of the provisions of Article 33 Paragraph (3) of the 1945 Constitution that the Earth and water and space, including the natural resources contained therein at the highest levels controlled by the State as the people power organization. This entails an understanding that the owner of the land, water and air space as well as all natural resources contained therein is Indonesia as a Nation. It means that the State the only authorized to control of the land, water, space and natural riches contained therein, determine the allocation and use, regulating and managing the natural resource contained therein mainly for the improving of

\footnotetext{
${ }^{9}$ Bintoro Tjokromidjojo, Reformasi Nasional dan Penyelenggaran Good Governance dan Perwujudan Masyarakat Madani (National Reformation and the Implementation of Good Governance for the Improvement of Civil Society), 37 (Lembaga Administrasi Negara, Jakarta, 2002).

${ }^{10}$ Imam Kuswahyono, Op. Cit., at 219.
} 
welfare and prosperity the whole people of Indonesia.

Referring to Article 1 Paragraph (2) the 1945 Constitution it can be concluded that the people are sovereign on natural riches in the country of Indonesia. That is why in the State's laws and legislation has been defined that the Government is not a legal subject that has right to transfer State's assets and property as of the wealth of Indonesia particularly in the form of lands and buildings on it. It is therefore the mentioned constitutional and legal framework indicates that there is conflict of legal norm between Article 33 Paragraph (3) of the 1945 Constitution, as well as Article 2 Act No. 5 of 1960 on BAL with Article 45 Paragraph (1) and (2), Article 46 Paragraph (1), Article 49 Paragraph (1) and (3) of the Act No. 1 Year 2004 concerning State Treasury and the Government Regulation No. 27 Year 2014 concerning Management of Central and Regional Government's Assets as well as Minister Regulation No. 17 Year 2007 on Technical Guidelines for Management of the Regional Government's Assets.

Unavailability of the clearly legal instrument especifically in governing procurement of goods and services through ruilslag also is a factor contributing to the lack of implementation of procurement of goods and services through ruilslag. Procedures and standard in the procurement system still contains weaknesses namely what opens up the possibility of irregularities in the procurement processes because there is a legal loophole employed certain elements to gain personally. ${ }^{11}$

In the implementation of the procurement of goods and services performed by the Government up till now refers to Article 1320 Burgerlijk Wetboek (BW/Indonesia Private Law) and the various Presidential Decree that regulating the implementation of budget revenue and expenditure and are guided by the Ministry Regulations concerning to the procurement of goods and services. The implications of such a situation would affect legal certainty of the procurement of goods and services through the exchange (ruilslag).

The procurement goods and services through the exchange in principally carried out with the tender which was then followed by the manufacture of various officially documents and administration has been a series that can not be separated from one to another. Hence, the necessary and clearly legal instrument governing transparency of the procurement of goods and services covering all stages of procurement in order to satisfy the principle of transparency through the mechanism of ruilslag.

From the historical point of view ruilslag or the exchanging of wealth

${ }^{11}$ Abu Sopian, Op. Cit., at 49; Muhamad Nurahmad, Op. Cit., at 63. 
and assets in the era of Dutch colonization has been an anomaly that not only raises the issue of legal aspects, but also related to the economic and political problems as well as defense and security dimensions. It is the so called anomaly since the exchange of assets of the Government gaps between what it should be (das Solen) with what is happening in the practice or implementation (das sein). ${ }^{12}$ It is because consequences of the ruislag potentially firstly a mismatch value between objects with objects origin exchanger, and secondly, the increasing number of corruption, particularly concerning the wealth and assets both from the executive and even the legisiative, as well as the third, in many cases regarding the exchange of wealth or assets either potentially who has been proven in the trial of a loss to the state, turned out to people as the owner of such property. In addition to not be able to obtain justice can not even make legal effort to save assets of the Government. ${ }^{13}$

Opinions have some similarities that the legal issues in legal dogmatic occur in the conditions: ${ }^{14}$

a. There are differences in the interpretation or even conflicting;

b. Text rules because of lack of legislation it;

c. A legal vacuum (rechtsvacuum);

d. There are differences in the interpretation of the facts.

Referring to the theory associated with legal materials were analysed, the authors argue that there is a conflict of norms so that there is a difference of interpretation of the laws and regulations governing the management and transition of wealth or assets of the Central and Regional Government. In this respect, the conflict of norm occurs between Article 33 Paragraph (3) the 1945 Constitution and Article 2 Law No. 5 of 1960 on BAL with the Article 45 Act No. 1 of 2004, Article 32 and Article 33 Paragraph (1) as well as Article 64 the Government Regulation No. 27 Year 2014, Article 57 b and Article 58, Article 59, Article 70 Paragraph (1) to Paragraph (3), and Article 74 Minister Regulation No. 17 Year 2007 on Technical Guidelines for Management Regionl Government Goods and Assets. The legal consequences that occurred after doing the exchange of Government wealth or assets constantly found elements of the loss on the Government because there is a difference between the original object with the value of objects exchanger.

\footnotetext{
${ }^{12}$ Philipus M. Hadjon and Tatiek S. Djatmiati, Argementasi Hukum (Legal Argumentation) 7 (Gadjah Mada, Yogyakarta: University Press, 2005).

${ }^{13}$ Imam Kuswahyono, Op. Cit., at 89.

${ }^{14}$ Bernard A. Sidharta, Ilmu Hukum Indonesia (Indonesian Legal Science), 100 (Penerbit Genta, Yogyakarta, 2005).
} 
With regard to what is outlined in advance, there is a relationship between the concept of the political history of law on how the process of formation and regulation as well as the system or the legal order governing public life in the country nationally. ${ }^{15}$ In particular the laws govern political history of wealth or assets with the question of why the State should regulate the exchange of Government assets, and the significance of why the issue of wealth or assets of the Govrnment should be organized and managed in accordance with the principle of expediency for the greatest prosperity of the people. The answers to these questions are that essentially wealth or assets of the Government that are expected to provide for the welfare of the people in a way be utilized to achieve the value and benefits of the highest order.

The validity of the procurement of goods and services through ruilslag also is essential in the legal procurement. Implementation of the procurement of goods and services, and the rights and obligations can only be claimed by one party to the other party, and vice versa if the procurement that made it lawful. Hence, the validity of the procurement of goods and services has been crucial that are legitimate should not be changed or canceled unilaterally, because the agreement contained in the procurement will become law for the parties that specifically regulate procurement that involve the Government as a legal party.

Transparency is the policy open to scrutiny. While the definition of information regarding every aspect of government policy that can be accessible to the public. Disclosure of information is expected to produce healthy political competition, tolerant, and public policy is made base on preferences. Transparency is one of the fundamental aspects for the realization of good governance and embodiment of good governance requires transparency, engagement, and ease of access for the public to the process of the Government.

The significance of transparency in governance can be viewed in two ways namely:

1. One form of accountability of Government to the people;

2. Efforts to improve the management and good governance and reduce the chance of collusion, corruption and nepotism.

Transparency as providing information on public administration and guaranteed the ease of obtaining information that is accurate and adequate. From this sense can be explained that transparency not only provides information about governance, but must be accompanied by convenience for

${ }^{15}$ Imam Kuswahyono, Op. Cit., at 46. 
citizens to obtain such information. For this respect at least there are three indicators that can be used to measure the level of transparency of governance. First, measure the degree of openness of the process of public service delivery; Second, that requirements, cost, time and procedures adopted must be published openly and easily to accessed by the needy, and tried to explain why; Third, indicator refers to how easily the rules and procedures can be understood by users and other stakeholders. In this sense rules and procedures are "simple, straightforward and easy to apply" or simple, direct and easy to apply to reduce the differences in interpretation. Therefore, the information obtained is free and readily available. ${ }^{16}$

Transparency is the openness of the Government in making policies of finance that can be known and monitored by the Legislature and the public. Tjokromidjoyo explained that transparency that can be known by stakeholders regarding the formulation of policy of the Government, organizations and business entities. Good governance does not allow government management is covered. ${ }^{17}$

In good governance does not allow a closed manner because there are eight aspects of the mechanism of state budget management should be done in a transparent manner as follows: ${ }^{18}$

(1) Determination of the position of office or position;

(2) The wealth of public officials;

(3) The award;

(4) Determination of policies related to the enlightenment of life;

(5) Health;

(6) Morality officials and officials of public servants;

(7) Security and order;

(8) Policy strategy for an enlightened society.

The concept of transparency according to the Organisation for Economic Cooperation and Development (OECD) is as follows: ${ }^{19}$

Transparency is a core governance value. The regulatory activities of government constitute one of the main contexts within to which transparency must be assured. There is a strong public demand for greater transparency which is substantially related to the rapid increase in number and influence of nongovernmental organisations or “civil society groups”, as well as to increasingly well educated and diverse populations.

\footnotetext{
${ }^{16}$ Agus Dwiyanto, Reformasi Birokrasi Publik di Indonesia (Reformation of the Indonesian Public Bureaucracy), 80 (PSSK, Yogyakarta, 2006).

${ }^{17}$ Bintoro Tjokromidjojo, Op. Cit., at 123.

${ }^{18}$ Agus Dwiyanto, Op. Cit., at 184.

${ }^{19}$ Bintoro Tjokromidjojo, Op. Cit., at 66.
} 
Concept of transparency is the main value of the Government's system. Main activity of the Government must be believed to be based on transparency. There is a public authority that demands greater transparency. This means that public demand for transparency is getting stronger in good governance. Smith on the other hand argued that the process of transparency includes: $:^{20}$

Standard procedural requirements, that the rule-making process should involve participation and attention to the needs of the community.

Consultation processes, existence of dialogue between Government and society.

Appeal rights (application for License) are the main protector in the regulatory process. It should be standard, straightforward and transparent to avoid corruption.

Misbah Hidayat suggested that transparency means people should be able to obtain information freely and easily about the process and the implementation of the decisions taken. In general, public accountability will not happen without supported transparency and clarity of the rule of law. ${ }^{21}$ Transparency is the policy open to scrutiny, while the meaning of information regarding every aspect of government policy that can be accessible to the public. Disclosure of information is expected to produce healthy political competition, tolerant and policies are based on public preferences. $^{22}$

Transparency is built on the basis of free flow of information and the whole process of government, institutions and information needs to be accessible to the interested parties, as well as the information provided should be sufficient to be understood and monitored. Hence, it can be concluded that both have significant correlation in which government can be said to be good governance, and means that the government has implemented principles of transparency included transparency, integrity, accountability, responsibility and participation.

The principle of transparency can be measured through a number of indicators as follows:

(1) The existence of a system of openness and standardization are clear and easy to understand all the processes of governance.

(2) The existence of a mechanism that facilitates public questions about the processes in governance.

(3) The existence of a mechanism for reporting and dissemination of

\footnotetext{
${ }^{20}$ Bintoro Tjokromidjojo, Op. Cit., ibid, at 66.

${ }^{21}$ Misbah Hidayat, Op. Cit., at 23.

${ }^{22}$ Meuthia Ganie Rahman, Op. Cit., at 151.
} 
public information officers in action irregularities in the activities of governance.

In accountability entails an obligation to present a report on all actions and activities particularly in the field of financial administration to interested parties. In this case accountability has been seen from the viewpoint on task achievement. As quoted by the Financial and Development Supervisory Agency (FDSA), the notion of financial accountability is accountability regarding financial integrity, disclosure, and compliance with laws and regulations. Goals are the responsibilities of financial statements that are presented include the receipt, storage, and spending money. ${ }^{23}$

Something to be achieved that is certainly related to the intent of the establishment of the company or in other words, the purpose directly related to the reason for the existence of the company. In an effort to determine whether the objectives that have been set is reached or not, need to be made standard on the level of achievement of the desired. This means we need a benchmark to determine whether the activities undertaken have achieved the objectives established by the company since its inception.

In the implementation of accountability need to pay attention to the following principles:

(1) There must be a commitment from the leadership and the entire staff of the agency to manage the implementation of the mission to be accountable.

(2) There must have a system that can ensure proper use of resources is consistent with the legislation in force.

(3) Must be able to show the level of achievement of goals and objectives that have been set.

(4) Must be oriented vision and mission as well as the results and benefits.

(5) To be honest, objective, transparent and inovative as catalysts for change management in the form of an update mechanism and performance measurement techniques and the preparation of reports are accountable.

II. TRANSPARANCY PRINCIPLE IN THE PROCUREMENT GoOdS AND Government Services through the EXCHANGe (RUiLSLAG) METHOD AND MECHANISM

In relation to the principle of transparency in the procurement of goods and services as stipulated in Presidential Decree No. 4 of 2015 on

\footnotetext{
${ }^{23}$ Bintoro Tjokromidjojo, Op. Cit., at 98.
} 
Procurement of Goods and Government Services, the Government should proactively provide comprehensive information on policies and services made available to the public, especially in the procurement of government goods and services through ruilslag. The Government must set up a clear policy and the policy will clarify the form of an accessible information or forms of confidential information, how to get information, a long time getting the information and complaint procedure if the information is not up to the public.

Basic instruments of transparency are the rules that guarantee the right to information, while supporting instruments is a database facility and means of information and communication and dissemination of the products instructions and information in government organizers, as well as complaints procedures. As such, the regulation is a legal product that is guaranteed to set about the right to obtain access to and dissemination of information to the public. Moreover, transparency has become a sort of ethical international relations that must exist to ensure the implementation of system of government that is accountable and transparent is one key to good governance nature.

In the foregoing system included several prerequisites that must be met when transparency and accountability into a barometer. Among the prerequisites it is a guarantee that all the important events of government activities are well documented with clear measures and can be summarized through a process of information where we can see everything that is going on. With the transparency of government that is supported by a clear legal umbrella will add insight and knowledge society to governance. In this respect, increased public confidence in the government will ensure the increasing number of people who participated in the national development and will be able to minimize the reduction in violation and deviations in governance.

The emergence of regional regulations on transparency helps provincial and district public trust in governance at the level of regional administrations. The trouble is there is no political will from the Government to effectively implement the transparency regulations. Although it has been created, for now we can see the implementation of the regional regulations on transparency is ineffective. Transparency is still not into the spirit of the paradigm and ethics in governance. Whereas in the regulation includes an obligation public bodies to release information actively on the regional development plan, including the budget, start planning, discussion, until the determination, spatial plans to the establishment, implementation of development activities as well as structure, 
and tasks of public bodies related procedures to obtain public information.

In the level of implementation the presence of the regulation is only complementary and as entertainers in order to drown out the loud voices that encourage transparency in governance. The presence of these legal rules is just as any form of justification that the governance seemed to have good intentions for and has been transparent. The regional government considers that transparency has been accomplished when regional regulation has been enacted. The regional government used to make the decision but failed in its implementation. The executive responded that the regional governance as misperceptions about the implementation of transparency, meaning that executives do not know and understand about the regulation. This is because the executive do not understand or lay on good governance as embodied in the spirit of transparancy principle.

In this sense Tjokromidjoyo explained that transparency that can be known by many parties regarding the formulation policy of the Government, organizations and business entities. Good governance does not allow government management is covered. ${ }^{24}$ This means that the transparency in the procurement of goods and services through ruilslag aims to be known by many parties regarding formulation of the Government's policy in the implementation of ruilslag that good governance is achieved. It is because the good governance do not allow the ways closed as consistent with the concept of transparency according to the Organisation for Economic Cooperation and Development (OECD).

The concept of transparency is a core value system of governance. The works and main activities of the Government should be believed to be based on transparency. There is a public authority that demands greater transparency. In principally, this means that public demand for transparency has been getting stronger because of the transparency policy open to the procurement of goods and services through ruilslag for supervision, while the meaning of information regarding every aspect of government policy that can be accessible to the public.

By looking at the above description, the principle of transparency can be measured through a number of indicators as follows:

a. The existence of a system of openness and standardization are clear and easy to understand all the processes of governance.

b. The existence of a mechanism that facilitates public questions about the processes in governance.

c. The existence of a mechanism for reporting and dissemination of

\footnotetext{
${ }^{24}$ Bintoro Tjokromijoyo, Op. Cit., at 7.
} 
public information officers in action irregularities in the activities of governance.

In relation to the principle of transparency in procurement of goods and services through the ruislag (the exchange) as stipulated in Presidential Decree No. 4 of 2015 can be clarified that the type of goods and services required by Government classified into four types namely: ${ }^{25}$

\section{a. Goods}

Every object is either tangible or intangible, movable or immovable, include lands which have many goals as traded and used by consumers.

b. Construction work

All work related to the implementation of the construction or the manufacture of other physical form.

\section{c. Consulting services}

Services are professional services that require specific expertise in various fields of science that prioritize their process to think.

d. Other services

Is a service that requires a certain ability that promotes skills in the system of governance in addition to consulting services? Such as catering services, hygiene services, provision of labor services, importing and tailoring services and others.

The mentioned Presidential Decree No. 4 of 2015 and Minister Regulation No. 17 Year 2007 used as a handbook for people who involved in the process of procurement of goods and services. In this respect, there are two procurement organisations that procure goods and services through self-management and the procurement by providers of goods and services. ${ }^{26}$ Procurement of goods and services that the Government intended to obtain goods and services with the criteria of the right price, right quality, right quantity, as well as partners and the way procurement is right and the other agreements in accordance with the agreements made so that the user can utilize the goods and services.

In order to obtain goods and services conducted through ruilslag, there are basic principles that must be followed includes efficient, effective, openess, competitive, as well as transparent, fair and non-discriminatory and accountable. Therefore, basic principles of the legal basis are for the parties namely providers and users, and if it does not follow the basic principles it will be intended to deal with law enforcement.

Procurement of goods and services through ruilslag in government agencies is the primary duty where government agencies not to produce

\footnotetext{
${ }^{25}$ Abu Shopian, Op. Cit., at 5.

${ }^{26}$ Muchammad Nurachmad, Op. Cit., at 7.
} 
goods and services aimed at profit-oriented, but rather to provide public services. For that governments need the goods and services in order to improve public services on the basis of logical thinking and systematic, following the principles and ethics as well as based on the methods and processes of procurement or ruilslag applicable. Hence, procurement thro ugh the exchange (ruislag) can be done through a third party or selfmanagement. In case it is done through a third party ruilslag method conducted through auction, election, direct procurement, direct appointment, contests, sweeps takes or through selection. On the other hand, if it is carried out through self-management ruislag can be done by the agency itself, other government agencies or community groups.

Procurement through ruilslag which is conducted with selfmanagement and goods and services composed as follows: ${ }^{27}$

1. Procurement of goods and services with self-managed government.

a. Use of budget/power budget users;

b. Officials commitment maker;

c. Committee/receiver official results of the work.

2. Procurement of goods and services through the government's goods and services provider.

a. Users budgets/power budget users;

b. Officials commitment maker;

c. Procurement services unit/procurement officer;

d. Committee/receiver official results of the work.

Therefore, the procurement of goods and services of any kind are used including through ruilslag is expected to occur suitability and transparency which includes the prosedure done starting from the procurement tender process in order to achieve the purpose of procurement of goods and services for the benefit of society. Ruilslag further relates to the implementation, there are some things that need to be understood about the procurement of goods and services through ruilslag namely: ${ }^{28}$

1. Ruilslag is a form of legal relationship or agreement involving two parties, namely government agencies that have land or buildings either other parties or legal entity that will provide the land and building a replacement.

2. In ruilslag obtaining one of the parties involved government agencies and the private sector as the other party;

3. Object of ruilslag agreement covers transfer of land and building of government institutions to other parties as well as the provision of land and building a replacement to be diverted from other parties to the government

\footnotetext{
${ }^{27} \mathrm{Ibid}$, at 7.

${ }^{28}$ Sogar Simamora, Op. Cit., at 127.
} 
agencies.

It means that ruilslag not the only an agreement to exchange or purchase or procurement as stipulated in the regulations related to procurement for government agencies. However ruilslag is a form of naming the new agreement regulated beyond the Indonesian Private Law. In this respect, as a new form of agreement ruilslag contains elements of the exchange agreement in the procurement of goods and services. In the method of ruilslag the goods mainly land and or buildings are owned by each party that will be mutually delivered or interchangeable from one party to the other party. In the exchange agreement, the goods delivered by each party to the other in the condition and status of what their rights and when there is agreement and handover. If the goods under certain conditions and are in status property rights or rights of use, the goods were handed over or exchanged under the same conditions and its status as proprietary rights or the only use rights.

In ruilslag method and mechanism, lands and buildings handed over when the agreement is reached but status of land rights can not be left as it is because it must be adjusted in advance with the status of rights that can be owned by private parties based on the agreement. Land owned by government only existed right to use and the right that can not be owned by private parties should be released to the State. In one hand in ruislag method the cost is fully sourced from the Government and consequently from the beginning status of goods mainly land and or building as wealth or property of the Government. On the other hand in ruilslag agreement, the cost to provide the land and the building is fully sourced from private parties who performed in the agreement. Consequently the land and buildings at first status property or possession of private parties until then the owner is processed for submission to government agencies.

\section{CONCLUSION}

The procurement of goods and services as stipulated in the Act No. 1 Year 2004 concerning State Treasury and the Government Regulation No. 27 Year 2014 concerning Management of Central and Regional Government's Assets and Presidential Decree No. 4 of 2015 on the Procurement of Goods and Government Services, as well as Government Regulation No. 27 Year 2014 concerning Management of Central and Regional Government's Assets and Minister Regulation No. 17 Year 2007 on Technical Guidelines ofthe Regional Government's Assets Management have been allowed by employing ruilslag method and mechanism in the 
time that unavaibility of Government's budget for the work of public services and providing infrastructures in order to realising prosperty for the people as mandated by the 1945 Constitution.

Ruilslag is a form of legal relationship or agreement involving two parties namely the Government agencies that have land or buildings either other parties or legal entity that will provide the land and building a replacement. In ruilslag obtaining one of the parties involved the Government and the private sector as the other party. The object of ruilslag agreement covers transfer of land and building of the Government institutions to other parties as well as the provision of land and building a replacement to be diverted from other parties to the Government.

In ruilslag method always involve the Government, it could be Central or Regional Government, and it is therefore the procurement of goods and services through ruilslag sets out principle of transparancy for the purpose of achieving good governance nature in the democratic country of Indonesia. For this respect, ruilslag as a form of agreement in the procurement of goods and services has absolutely been subject to be accommodated and regulated within laws and legislation concerning the procurement of goods and services included assets and property of the Government.

The meaning of the Exchange (ruislag) of goods belonging to the Government mainly in the form of lands and building is a legal act conducted by the Government based on discreationary power due to the specific interest and urgent condition namely there has been unavailability Government's budget to provide infrastructures in the administrative work of good public services for the people in the country. On the other hand, the essence of transparancy is the core governance value. The regulatory activities of government constitute one of the main contexts within to which transparency must be assured as a strong public demand for greater transparency which is substantially related to the rapid increase in influence of non-governmental organisations in the country.

That is why principle of transparency is actually the main value of the governance system. Administrative activity of the Government must be believed to be based on transparency and that is a public authority that demands greater transparency. In essence will be nothing to do with the acceleration and impact on the administrative works of the Government in pursuing public services and improving good governance without transparancy. It is therefore public demand for transparency is getting stronger particularly in the procurement of goods and Government services in the country. 